\title{
Construction and Standardization of Risk Taking Ability Scale
}

\author{
Dr. P. Ganesan, C. Arul Joseph Raj \\ Reader, Department of Education, Annamali University, Annamalai nagar - 608002 \\ PhD Scholar, Manonmanium Sundaranar University, Abisekapattai, Tirunelveli - 6027012
}

\begin{abstract}
First draft is analyzed by the experts for the relevance of areas, item difficulty, language accuracy and clarity. The initial draft consisted of 108 items with five areas. It includes both the positive and negatives statements. A try-out study is conducted with a sample size of 100 students of $11^{\text {th }}$ standard. The individual score for the 100 sample is found out. Top 27 is taken as high sores and the bottom 27 is taken as Low scores $t$ values for all the 108 items are calculated. Items with t-value above 2.0 are accepted. and the below 2.0 are rejected. Reliability coefficient of Risk taking ability Inventory is found to be 0.88 . The Risk Taking Ability Scale is given to the experts in order to find out its content validity. The experts agreed that the items in the scale provided adequate coverage about the concept. After item analysis it is found that 59 items are selected and 49 items are rejected.
\end{abstract}

\section{Understanding Adolescent Risk-Taking Ability}

Adolescents are at the peak of their physical strength, resilience, and immune function of their lifecycles. Adolescents take risks to test and define themselves. Risk-taking is both beneficial and harmful. It can lead to situations where new skills are learned and new experiences can prepare them for future challenges. Risk-taking serves as a means for discovery about oneself, others and the larger world. The natural and normative proclivity for risk-taking plays a central role in adolescent development, making it a time of both great potential and great vulnerability.

\section{Two elements on Risk Taking ability}

In our country most of the people are willing to take risk. They will say that they are risk takers, they have high Risk appetite, they love challenge, and all kind of nonsense. But they forget to consider their "Ability to take risk". It's not important enough whether you are willing to take risk or not, your situation should also allow you to take risk. Ignoring your "Ability to take risk" can lead to situation like above example.

Willingness to Take Risk : This depends on our inherent nature, our attitude towards life, finance domain , Knowledge of financial products etc. Our whole upbringing will contribute towards this, because our willingness to take risk will depend on our inherent self, who we are from inside. This is the answer to "Can you take risk?"

Ability to Take Risk : This is the next Important part in Risk taking. It has no link with willingness to take risk. It is the process of developing skills to face the risky situation boldly. Here they know the good and bad of the risky situation. This is the answer to "Shall you take the risk?"

\subsubsection{STANDARDIZATION}

For the Standardized test

1. Objective type of items are included

2. Reliability and validity of the test are estimated.

3. Item analysis is done to select appropriate items of the test.

4. It is for well defined population or for particular area.

5.It is mainly for research work, guidance, counselling and for administrative uses.

6. It is used for the comparison of two groups or several groups.

Based on these previous studies, the researcher found FIVE factors are suitable for the adolescent population namely Ethical risk taking, Social risk taking, Health-safety risk taking, Recreational risk taking and Academic risk taking. Based on that statements are written.

\subsubsection{CONTENT ANALYSIS}

First draft is revised by an expert committee comprising of teacher educators of the sample students and experts in Psychology. The tool is analyzed by the experts for the relevance of areas, item difficulty, language accuracy and clarity. 
Each and every item is analyzed and the relevancy of the items are judged by the experts. The difficulty of the language was analyzed by the English language teachers.. Thus the initial draft consisted of 108 items with five areas. It includes both the positive and negatives statements.

\subsubsection{PRELIMINARY TRY-OUT}

A try-out study is conducted with a sample size of 100 students of $11^{\text {th }}$ standard. They are selected from five different schools of Cuddalore town including boys, and girls using random sampling procedure.

\subsubsection{ITEM ANALYSIS}

The individual score for the 100 sample is found out. Top 27 is taken as high sores and the bottom 27 is taken as Low scores. $\mathrm{t}$ - values for all the 108 items are calculated. Items with $\mathrm{t}$ - value above 2.0 are accepted. and the below 2.0 are rejected.

Reliability and validity are major considerations when using standardized test and inventories.

\subsubsection{Reliability}

Reliability refers to the consistency with which a test measures, whatever it measures. The concept of reliability suggests both stability and consistency of measurement.

\section{Table 3.8 Reliability coefficient of Risk taking ability Inventory}

\section{Table -1}

\begin{tabular}{|l|l|l|}
\hline SI. No. & $\begin{array}{l}\text { Reliability } \\
\text { Technique }\end{array}$ & $\begin{array}{l}\text { Reliability } \\
\text { value }\end{array}$ \\
\hline 1 & Test retest reliability & 0.89 \\
\hline 2 & Split half reliability & 0.88 \\
\hline
\end{tabular}

\subsubsection{Validity}

The Risk Taking Ability Scale is given to the experts in order to find out its content validity. The experts agreed that the items in the scale provided adequate coverage about the concept.

\subsubsection{Final draft}

After item analysis it is found that 59 items are selected and 49 items are rejected.

\section{Risk Taking Ability Scale}

Read the following statements. In each statement there are five alternatives. You have to shade in any one of them whichever you think is suitable and correct. Do not leave any statement unanswered. Your answers will be kept confidential. (Answer in coding sheet )

\begin{tabular}{|c|c|c|c|}
\hline Always & $\begin{array}{c}\text { Most of the } \\
\text { times } \\
1\end{array}$ & Sometimes & Never \\
\hline
\end{tabular}

1. I reveal friend's secret to someone else.

2. In the presence of my friend, without his permission,

I take out his purse from his bag.

3. I leave home without telling anything to Parents.

4. I argue with my parents without considering their parental care.

5. I won't come out of the shop without paying the bill.

6 . I boldly point out the mistakes of elders.

7. I can argue the wrong as correct.

8. I take others work on my own.

9. I tease my innocent friends.

10. I try to test those who are living with principles

11. I never stop anyone who comes to my house

12. I say, others work as mine.

13. I never wait for chance, but I can make it.

14. I steal additional TV cable connection from the neighbor who is paying for it.

15. It is bad luck, if a black cat crosses my path $\square$

16. I don't notice little details.

17. Rules are meant to be broken. 
18. I never like repetitive tasks.

19. I consider the pros and cons of a decision before I proceed

20. I put my parent/ principal's signature.

21. My tastes are different from those of a friend.

22. I choose my career which is enjoyable and more secure one.

23. I park my cycle with others in an unsafe place.

24 . I check the expert's opinions before taking any decision.

25 . I continue with an activity that others have cautioned.

26. I will go against the rules if I know I won't get caught.

27. I carefully lock my residence

28. I avoid helping others because I may lose something

29. I f I know I am right, I won't change my mind even after the discussion with others.

30. It is better to ask for permission than to beg for forgiveness

31. I will take a bigger risk if there is a reward at stake. (i.e. money or recognition)

32. To perform well, I need to know the outcome of my work in advance.

33. I jump into new situations without much thought.

34. I disagree with my parents on my career decision.

35. I argue with my friends about the issue in which they have different opinion.

36. I defend unpopular issue.

37. I wear outdated or unconventional dress during festival seasons.

38. I am more prestigious than enjoyable.

39. life insurance is not essential

40. I act first and think later

41. I make hasty decisions.

42. Power of understanding is the best guide to make decision.

43. I am uncomfortable in unfamiliar situation.

44. Changing your mind is the sign of weakness

45. I walk in the sunlight without wearing cap or cooling glass.

46. I walk alone at night in the unsafe area.

47. I consider the safety of my friends when planning to go for picnic.

48. I cross the road behind the careful companion

49. I don't see the signal on crossing the road but I see the vehicles.

50. During rainy season I go without umbrella.

51. I ride on my bicycle without applying brake even in the slope.

52. I don't wear woolen clothes during winter because I feel uneasy.

53. Whenever the bus starts I hold the handle tightly

54. I avoid uncertain situations because I may lose something.

55. I go outside even after the threatening weather is forecast.

56. When I travel by train I sit near the emergency exits

57. I go for regular health check up

58. In a two wheeler it is better to drive than to be a pillion rider.

59. I ignore warnings because they will be resolved before I reach it.

60. I never see the expiry date of the medicine.

61. I am taking high cholesterol food.

62. I take Ice cream or cool drinks after every meal

63. I go for mountain climbing in a dangerous sport.

64. I heat the test tube without test tube holder.

65 . I check for fire exits when I go to new places.

66 . I wash my hands before taking food.

67. I never read the nutrition information on food items before I buy them.

68 . I ride on my bicycle without holding the hand bar.

69. I swim against the flow of water.

70. I raft at high water in the spring.

71. I bet my pocket money in the poker game.

72. I know how to play rummy.

73. If I won money in a game of chance, I would keep the money rather than continue playing.

74. I like to sit at the back of a person who drives over the speed limit.

75. I can't get into the moving bus 
76. I never involve lottery competitions

77. I shoplift small things.

78. I travel without ticket.

79. I travel on the foot board of the bus to show my bravery.

80. I say that I am a powerful person.

81. I hold ice cubes in my hand for a long time.

82. I won't get money from my parents by telling lies.

83. I spend the stolen money with my friends.

84. I attract the attention of others by my distinguished activities.

85. I like to play in waves and tides.

86. I show that I have a fluency in English.

87 . I try to cheat only my friends.

88. I come out of the school campus during class hours without seeking permission.

89. I participate in students' strikes.

90.I will complain to the principal/Headmaster if my subject teacher beats me for my mistake.

91. If I get a chance to be a class leader I will readily accept.

92. I take the difficult tasks first.

93. I fight with my classmates.

94. I never skip any of my examinations.

95. I point out teachers' little mistakes on the black board.

96. I like competitive examination rather than the school examination.

97. I think of tests as an opportunity to see what I have learnt.

98. I approach my teacher to ask for marks.

99. I try to cheat the invigilator during the examination.

100. I purchase the stolen cell phone from my friend.

101. Meeting or seminars are a waste of voluble time.

102. By the combined effort of knowledge And controlling power, I will be selected as a leader.

103. I enjoy solving problems or puzzles or Sudoku.

104. I participate in the school level competitions.

105. I find philosophical arguments boring.

106. I think twice before I answer a question.

107. I playfully steal little things.

108. I never involve in malpractices

Table -2

Item analysis of Risk taking ability

The following table gives the $t$ - value calculated, the accepted items

and the rejected items. Items with $\mathrm{t}$ - value above 2.0 are accepted. and the below 2.0 are rejected.

\begin{tabular}{|l|l|l|l|l|l|}
\hline $\begin{array}{l}\text { Item } \\
\text { No. }\end{array}$ & t- value & $\begin{array}{l}\text { accepted/ } \\
\text { rejected }\end{array}$ & Item No. & t- value & $\begin{array}{l}\text { accepted/ } \\
\text { rejected }\end{array}$ \\
\hline 1 & 1.840732971 & rejected & 22 & 1.291092396 & rejected \\
\hline 2 & 4.153050628 & accepted & 23 & 1.465192476 & rejected \\
\hline 3 & 4.286214897 & accepted & 24 & 0.554700196 & rejected \\
\hline 4 & 3.625074462 & accepted & 25 & 2.292592607 & accepted \\
\hline 5 & 1.507263965 & rejected & 26 & 5.292406046 & accepted \\
\hline 6 & 2.076266079 & accepted & 27 & 0.105095336 & rejected \\
\hline 7 & 2.606443628 & accepted & 28 & 1.696377859 & rejected \\
\hline 8 & 1.476992501 & rejected & 29 & 0.689513286 & rejected \\
\hline 9 & 2.793674662 & accepted & 30 & 0.886134809 & rejected \\
\hline 10 & 3.575509127 & accepted & 31 & 1.758377631 & rejected \\
\hline 11 & 0.090909091 & rejected & 32 & 0.67243878 & rejected \\
\hline
\end{tabular}


Construction And Standardization Of Risk Taking Ability Scale

\begin{tabular}{|c|c|c|c|c|c|}
\hline 12 & 1.010031429 & rejected & 33 & 3.378876974 & accepted \\
\hline 13 & 0.764852927 & rejected & 34 & 3.975458831 & accepted \\
\hline 14 & 2.293126025 & accepted & 35 & 1.372388933 & rejected \\
\hline 15 & 0.540157915 & rejected & 36 & 2.533916279 & accepted \\
\hline 16 & 5.343892034 & accepted & 37 & 4.355575104 & accepted \\
\hline 17 & 4.595007504 & accepted & 38 & 0.876493354 & rejected \\
\hline 18 & 1.577771118 & rejected & 39 & 0.716203169 & rejected \\
\hline 19 & 0.606806398 & rejected & 40 & 2.842553517 & accepted \\
\hline 20 & 2.991360541 & accepted & 41 & 1.950413096 & rejected \\
\hline 21 & 0.093219309 & rejected & 42 & 0.945456475 & rejected \\
\hline 43 & 0.203230463 & rejected & 66 & 0.546044996 & rejected \\
\hline 44 & 0.425154555 & rejected & 67 & 4.4259097 & accepted \\
\hline 45 & 2.329336054 & accepted & 68 & 5.222178777 & accepted \\
\hline 46 & 3.483980704 & accepted & 69 & 2.495637583 & accepted \\
\hline 47 & 1.087114613 & rejected & 70 & 3.08503097 & accepted \\
\hline 48 & 1.674035606 & rejected & 71 & 2.905436016 & accepted \\
\hline 49 & 3.308680767 & accepted & 72 & 2.229481607 & accepted \\
\hline 50 & 6.003996537 & accepted & 73 & 0.512614595 & rejected \\
\hline 51 & 8.100469923 & accepted & 74 & 4.60354255 & accepted \\
\hline 52 & 2.500552086 & accepted & 75 & 1.997334398 & rejected \\
\hline 53 & 1.533797902 & rejected & 76 & 0.52937654 & rejected \\
\hline 54 & 1.214288534 & rejected & 77 & 3.434291024 & accepted \\
\hline 55 & 7.720649005 & accepted & 78 & 2.646565764 & accepted \\
\hline 56 & 0.737308728 & rejected & 79 & 6.942458808 & accepted \\
\hline 57 & 1.080451356 & rejected & 80 & 0.091967577 & rejected \\
\hline 58 & 0.63335101 & rejected & 81 & 4.599444388 & accepted \\
\hline 59 & 3.188287148 & accepted & 82 & 1.614066424 & rejected \\
\hline 60 & 3.79294588 & accepted & 83 & 2.857392074 & accepted \\
\hline 61 & 4.298679594 & accepted & 84 & 2.404769875 & accepted \\
\hline 62 & 2.540380789 & accepted & 85 & 2.762324163 & accepted \\
\hline 63 & 2.099233113 & accepted & 86 & 2.160523907 & accepted \\
\hline 64 & 2.184577829 & accepted & 87 & 1.553625947 & rejected \\
\hline 65 & 0.915688889 & rejected & 88 & 5.22528039 & accepted \\
\hline 89 & 2.748309363 & accepted & 99 & 5.788363727 & accepted \\
\hline 90 & 2.32297792 & accepted & 100 & 2.982132063 & accepted \\
\hline 91 & 2.753337176 & accepted & 101 & 4.498896599 & accepted \\
\hline 92 & 1.146563012 & rejected & 102 & 0.465717292 & rejected \\
\hline 93 & 4.92085244 & accepted & 103 & 0.293199934 & rejected \\
\hline 94 & 0.602292507 & rejected & 104 & 0.634356025 & rejected \\
\hline 95 & 0.704570825 & rejected & 105 & 3.939051794 & accepted \\
\hline 96 & 2.339886191 & accepted & 106 & 0.751809412 & rejected \\
\hline 97 & 1.21474106 & rejected & 107 & 6.088519628 & accepted \\
\hline 98 & 2.108059988 & accepted & 108 & 1.490869308 & rejected \\
\hline
\end{tabular}




\begin{tabular}{|c|c|c|c|}
\hline Always & $\begin{array}{c}\text { Most of the } \\
\text { times } \\
1\end{array}$ & Sometimes & Never \\
\hline 2 & 3 & 4 \\
\hline
\end{tabular}

\section{SELECTED ITEMS FOR FINAL STUDY}

1. In the presence of my friend, without his permission,

I take out his purse from his bag.

2. I leave home without telling anything to Parents.

3. I argue with my parents without considering their parental care.

4. I boldly point out the mistakes of elders.

5. I can argue the wrong as correct.

6. I tease my innocent friends.

7. I try to test those who are living with principles

8. I steal additional TV cable connection from the neighbor who is paying for it.

9. It is bad luck, if a black cat crosses my path

10. I don't notice little details.

11. Rules are meant to be broken.

12. I put my parent/ principal's signature.

13. I park my cycle with others in an unsafe place.

14. I will go against the rules if I know I won't get caught.

15. I jump into new situations without much thought.

16. I disagree with my parents on my career decision.

17. I defend unpopular issue.

18. I wear outdated or unconventional dress during festival seasons.

19. I act first and think later

20. I walk in the sunlight without wearing cap or cooling glass.

21. I walk alone at night in the unsafe area.

22. I don't see the signal on crossing the road but I see the vehicles.

23. During rainy season I go without umbrella.

24. I ride on my bicycle without applying brake even in the slope.

25. I don't wear woolen clothes during winter because I feel uneasy.

26. I go outside even after the threatening weather is forecast.

27. I ignore warnings because they will be resolved before I reach it.

28. I never see the expiry date of the medicine.

29. I am taking high cholesterol food.

30. I take Ice cream or cool drinks after every meal

31. I go for mountain climbing in a dangerous sport.

32. I heat the test tube without test tube holder.

33. I never read the nutrition information on food items before I buy them.

34. I ride on my bicycle without holding the hand bar.

35. I swim against the flow of water.

36. I raft at high water in the spring.

37. I bet my pocket money in the poker game.

38. I know how to play rummy.

39. I like to sit at the back of a person who drives over the speed limit.

40. I shoplift small things.

41. I travel without ticket.

42.I travel on the foot board of the bus to show my bravery.

43. I hold ice cubes in my hand for a long time.

44. I spend the stolen money with my friends.

45. I attract the attention of others by my distinguished activities.

46. I like to play in waves and tides.

47. I show that I have a fluency in English.

48. I come out of the school campus during class hours without seeking permission.

49. I participate in students' strikes.

50.I will complain to the principal/Headmaster if my subject teacher beats me for my mistake.

51. If I get a chance to be a class leader I will readily accept.

52. I fight with my classmates.

53. I like competitive examination rather than the school examination. 
54. I approach my teacher to ask for marks.

55. I try to cheat the invigilator during the examination.

56. I purchase the stolen cell phone from my friend.

57. Meeting or seminars are a waste of voluble time.

58. I find philosophical arguments boring.

59. I playfully steal little things.

\section{Conclusion:}

The constructed Risk Taking ability Scale has 59 items which covers five areas namely Ethical risk taking, Social risk taking, Health-safety risk taking, Recreational risk taking and Academic risk taking with five point scale namely always most of the times, some times and never. 